\title{
Entrepreneurship Motivation in the 21st Century in Terms of Pull and Push Factors
}

\author{
Zsuzsanna Gódány ${ }^{1}$, Renáta Machová ${ }^{1}$, Ladislav Mura ${ }^{2}$, Tibor Zsigmond ${ }^{1}$ \\ ${ }^{I} J$. Selye University, Faculty of Economics and Informatics, Bratislavská cesta 3322, Komárno, Slovakia \\ ${ }^{2}$ Pan-European University, Faculty of Economics and Busines, Tematínska 10, Bratislava, Slovakia
}

\begin{abstract}
The socio-economic importance of entrepreneurship in the 21 st century in relation to economic growth has become undisputable on local and global level both in terms of macroeconomic indicators, as well as the micro environment. Despite the above, this field still offers questions to be addressed, and these are related to the entrepreneurs themselves, entrepreneurial behaviour, motivation to start business, but also the entrepreneurial environment that encourages or hampers their activities or attitudes. Entrepreneurial motivation is often related to push and pull factors. This study analyses entrepreneurial motivation through push and pull factors. The central aspiration of this research, which was conducted according to problem-oriented quantitative methodology, is founded on the information analysis from the respondents in the following fields: motivation to start business, attitudes related to success and financial vs. non-financial success. To answer the research question the questionnaire survey was chosen as a data collection method. Findings indicated that people quit their employment because they are forced to do as a result of certain push factors, which have fundamental influence on decision or motivation to start their own business.
\end{abstract}

Keywords - entrepreneurship, SME, pull and push factors, motivation.

DOI: 10.18421/TEM101-42

https://doi.org/10.18421/TEM101-42

Corresponding author: Ladislav Mura,

Pan-European University, Faculty of Economics and Busines, Bratislava, Slovakia.

Email: ladislav.mura@gmail.com

Received: 02 December 2020.

Revised: 04 February 2021.

Accepted: 11 February 2021.

Published: 27 February 2021.

(cc)BY-NC-ND (C) 2021 Zsuzsanna Gódány et al; published by UIKTEN. This work is licensed under the Creative Commons Attribution-NonCommercial-NoDerivs 4.0 License.

The article is published with Open Access at www.temjournal.com

\section{Introduction}

The social and economic importance of entrepreneurship in relation to economic growth on local and global level is undisputable. In addition, it is important to note that its importance is increasing as a scientific discipline that is evolving dynamically, but still unanswered and disputable questions are detected. These questions are related to entrepreneurs, entrepreneurial behavior, potentials, motivation to start business, but also the entrepreneurial environment, which is encouraging or hampering the entrepreneurial activity, attitude and aspirations. The attitudes towards entrepreneurship present the extent to which the country's population is entrepreneurially oriented in terms of entrepreneurship as a career choice. If entrepreneurship in society is a ,positive phenomenon", the individual knows enough entrepreneurs in his environment, and believes that successful entrepreneurs are socially recognized, he makes it easier to decide to follow this path. Similar applies in the case of entrepreneurial possibilities: if enough possibilities are identified, a positive impact on development of business is more likely. If people think they have enough knowledge, skill and experience to start a business, they are more likely to do that. The same applies if we think about fear and business failure. If the level of fear is high, individuals will seek other employment possibilities.

\section{Literature Review}

Before we focus our attention on motivating factors to start a business, we will address the phenomena of entrepreneurship. We can return to the 18th century, when the expression was introduced. The expression was introduced to practice by Richard Cantillon, who pointed out that the entrepreneur is taking risk especially in terms of providing capital [4], [5]. The provided explanation differs from the current understanding of entrepreneur and entrepreneurship. According to French economist J. B. Saya, the entrepreneur is a person, who is trying to move resources from low productivity areas into areas of high productivity 
[25]. Undoubtedly, one of the most important pioneers in the theory of entrepreneurship is Joseph Schumpeter [27], who defines the entrepreneur as a person constantly seeking opportunities and supporting innovation. By constantly trying to change the status quo, looking for profit and taking risk voluntarily in order to combine the resources of the company with applying new methods. According to Schumpeter, the entrepreneur is therefore a necessary destabilizing element of the environment [27]. The motivation of the individual has a decisive impact on the behavior of the individual. It cannot be considered as the only determinant. According to [14], [1], the performance of individuals is influenced by intrinsic nature and it is a reaction to internal circumstances. A person's intrinsic nature is influenced by the perceptions of the individual [26]. The decision to become an entrepreneur is determined by many factors e.g. age, education, family background, individual effort and abilities, and the external environment influencing the behavior [14]. Entrepreneurship is an activity of generating and implementing new ideas in a highly competitive, complex and uncertain environment [8], [15], [24]. Entrepreneurial activity is a catalyst to economic growth and sustainability, which also contributes to social development [31], [10]. The promotion of an entrepreneurial culture provides solution to combat low productivity, high rate of unemployment and economic stagnation [9]. Developing a business structure benefiting from dynamism, complexity and uncertainty of the business environment but also employing professionals is essential [17]. Development of entrepreneurship has direct relation with imperfection of the market and gaps of market functioning [19]. The entrepreneur is focusing on these gaps by discovering economic opportunities to fill efficiently and become an established player on the market. This kind of entrepreneurial attitude requires the entrepreneur to be aware of the current and future economic trends, and have an idea to utilize them, as well as to have knowledge about the legal aspects of entrepreneurship and choose the right time to enter the market considering the market gap and the competition. It is required the entrepreneur to be technically, technologically and financially skilled as well as prepared for the entrepreneurial activity and have a business plan prepared. Citing the modern theory of entrepreneurship, the entrepreneurial activity can be understood as a practical utilization of entrepreneurial opportunities as a result of market imbalance. It is a set of business activities that ensure the transition to equilibrium on higher level. Within the scientific approach to the study of motivation as a phenomenon, the scientific literature distinguishes a relatively large number of theoretical concepts that explain and clarify the concept of business motivation. When addressing this issue, we encounter a homeostatic, hedonistic, activating and supply model as well as the cognitive model, theory of needs and various other approaches [7]. Our research will focus on the analysis of push \& pull theory, focusing on factors affecting motivation. The research and theoretical approaches to entrepreneurship have undergone a very expansive development since the second half of the 20th century. The concept of entrepreneurship has its place also in the world economic theory and its content reflects the approach of representatives of different schools of economic theory. As an example, the following definition can be cited: "The essence of entrepreneurship is the independent decision-making about the legal form of the business, location of business activity, organization of activities, decision about the amount of foreign capital to be used, sharing the risk etc. The main purpose of entrepreneurship is to increase assets. It can be achieved in various ways. Producing goods or providing different services is the most common approach to satisfy the needs of customers", [28]. In certain situations, the opportunities available for entrepreneurs only need to be recognized [6], [20], while certain circumstances require particular skills to utilize the existing resources and turn them into an innovative idea with added value [11], [12]. The individual motivation plays a key role in recognizing and creating an opportunity. The international expansion of businesses has several different motivations. Some of the entrepreneurs seek an opportunity to make high profit, the others are about to introduce and test a new idea, while certain percentage of them can see an opportunity to escape the hostile conditions on the domestic market [32]. The decision to start a business, according to or [29] can be a rational and motivational decision. The rational decision is about adapting to the task and the environment that reinforces or punishes certain behaviors [23]. The motivational decision refers to the expectations of decision-makers. Starting with [13] emphasizes the connection between the need for achievement and the entrepreneurial behavior. The need for achievement expresses a strong desire to perform better in doing things than others. Individuals highly motivated by achievement are more likely to make plans. These are the individuals, who take on responsibility and keen on feedback about their conducted activities. The majority of studies emphasize the importance of the entrepreneurial feature "need to achieve" that has impact on the success of the business. [18] addressed to deal effectively with competence and the environment. Individuals would like to understand the physical and social environment and anticipate 
the output of its influence. The scientific literature emphasizes the internal control. It means that the individual believes in his or her actions, less importance is left to chance and luck. The achievement orientation is in line with the competitiveness since the entrepreneurs believe that their actions will have impact on the final result. As it is stated by [22], the scientific literature in the field of entrepreneurship deviates from the content-based approach to a dynamic-oriented approach. The focus is on contingency (contingency school), which approaches entrepreneurship as a reaction to random events the entrepreneur encounters. In the context of this direction, the personality traits required from the entrepreneur are influenced by the external entrepreneurial environment [22]. If this concept is accepted, the question arises, what kind of environment is the most appropriate to establish a new business. In other words, where does one get the motivation to become an entrepreneur and which factors have impact on this decision? Several researches were conducted in the field of motivation factors to establish a business. The scientific literature works with a classical, generally accepted theories defining the reasons and factors on general basis, which result the potential entrepreneur to start a business. The theory of push and pull motivators can be used to examine the motivation from different perspectives [2], [3]. According to experts and professional publications, individuals start a business either they have no other choice e.g. following longterm unemployment or they can see an opportunity to make profit for themselves. These two circumstances described above contributed to the emergence of push and pull theories, resp. necessity entrepreneurship and the opportunity entrepreneurship [8]. According to push theory, people are "pushed" into entrepreneurship as a result of negative circumstances they find themselves in. It can be described as a result of the conflict between the current situation the person finds himself, and the situation in which he would like to find himself [30]. We often talk about internal factors (forces) as a loss of workplace, long-term unemployment, inadequate salary, dissatisfactory working hours and other unfavorable conditions resulting in negative emotions. The pull theory of motivation (opportunity driven motives), in contrast to push theory will "pull the individual" and encourage to start entrepreneurial activity. They usually occur as a supply and take the form of external forces. They are often presented as opportunities, gaps on the market etc., which will stimulate the future entrepreneur to take on positive challenges. Although individual motivational factors can be recognized and identified as push or pull factors, there is a general consensus among the professionals that the motivation as a result is a combination of push and pull factors, which means that we do not talk about completely separate or different factors. Push motivators refer to internal aspects and emotional traits of the individual, while pull motivators are linked to external aspects, which stem from the subjective perception of the situation [16]. The motive in the case of push motivation is stronger, but short lived and often not leading to extraordinary results. On the other hand, pull motives are more permanent and do not fade. The success of entrepreneurs is built on these facts. The research also confirmed that ,pull entrepreneurs are more successful than "push entrepreneurs".

\section{Material and Research Methods}

The focus of the present study is to examine the motives of the entrepreneurs starting their business, and examine the relationship between the individual motives as well as what relation these motives have with the success indicator examined by us. The main goal of our research is to examine the relationship between the motives starting a business and the sense of success. In order to reach our objective, the following sub-goals were formulated:

- Examining the opinion of the respondents regarding the motives related to starting a business;

- Examining the opinion of the respondents based on their attitude to success;

- Examining the relationship between the pull motivation factors and the attitude to success;

- Examining the relationship between the push motivation factors and the attitude to success.

Based on the defined research goals, the following research questions and a hypothesis were formulated:

1. Research question: Is there a relationship between the pull factors related to start business and the attitude towards the success?

Based on the research question, the following hypotheses were formulated:

$\mathrm{H} 1_{0}$ : There is no relationship between the pull factors responsible for starting business and the entrepreneur's attitude feeling successful.

$\mathrm{H} 1_{1}$ : There is a relationship between the pull factors and the entrepreneur's attitude feeling successful.

2. Research question: Is there a relationship between the companies' push motives starting a business and the attitude to success?

$\mathrm{H} 2_{0}$ : There is no relationship between the push factors responsible for starting business and the entrepreneur's attitude feeling successful. 
$\mathrm{H} 2_{1}$ : There is a relationship between the push factors and the entrepreneur's attitude feeling successful.

Both primary and secondary data collection was conducted in the research. The secondary data were obtained from the informative article published by the European Commission and the latest annual report of the Slovak Business Agency.

In order to answer our research question, a questionnaire research as a primary, quantitative observation method was chosen. The questionnaire served to collect information from the respondents in the following fields:

- Motives related to start entrepreneurial activity;

- Attitudes related to success;

- Financial vs. non-financial success;

- Business data;

- Demographic data of the entrepreneur.

The questionnaire survey focused on the motives of entrepreneurs starting their business, exploring their attitude related to success as well as what is their attitude about the financial and non-financial motives of the success.

Motives related to starting a business and attitudes related to success were measured using a 7-point Likert scale. The research team opted for the Likert scale in measuring attitudes since we believe that indepth analyses can be performed in the case of variables measured on interval scale. This method would support the earlier research conducted. The pull motivation factor was measured using 9 variables, while the push motivation factor was measured using 8 variables. In addition to descriptive statistics, we performed a correlation analysis to test the hypotheses, and the Pearson correlation coefficient was used to determine the strength of the relationship between the variables.

Both macro and micro data were processed in our research. When collecting data, we were focusing on the SMEs operating in Slovakia. The research was conducted in southern parts of Slovakia, as the faculty of our university is focusing on this region. An arbitrary sampling procedure was used to select the companies in our sample. This technique enables to reach a larger number of companies. The questionnaire was completed by a total of 327 companies and the data were analyzed using the SPSS program.

\section{Research Results}

Our article focuses on SMEs. The small and medium sized enterprises play a key role in the European and the Slovak economy as well. According to Günter Verheugen, EU commissioner, responsible for the industrial and enterprise policy, the small and medium sized enterprises are the engine of the European economy. There are 23 million companies operating as SMEs in the EU providing 75 million workplaces. According to the latest survey [21], SMEs account for $99,9 \%$ of all the domestic enterprises. They employ more than twothirds $(73,2 \%)$ of the active workforce, and more than half $(54,6 \%)$ of value added is accounted for by SMEs. The data clearly show why it is necessary to devote attention to this group of players in the economy [21].

Table 1. Number of active business units based on the size of enterprises (2018)

\begin{tabular}{|l|c|c|}
\hline \multicolumn{1}{|c|}{ Company size } & $\begin{array}{c}\text { Number of } \\
\text { companies }\end{array}$ & $\begin{array}{c}\text { Percentage } \\
\text { (\%) }\end{array}$ \\
\hline Micro (0-9) & 542525 & 96,8 \\
\hline Small-sized (10-49) & 14328 & 2,6 \\
\hline Medium-sized (50-249) & 2988 & 0,5 \\
\hline Large companies (250+) & 680 & 0,1 \\
\hline Altogether SMEs & $\mathbf{5 5 9 8 4 1}$ & $\mathbf{9 9 , 9}$ \\
\hline $\begin{array}{l}\text { Altogether (SMEs+large } \\
\text { companies) }\end{array}$ & 560521 & 100,0 \\
\hline
\end{tabular}

Source: own editing based on data provided by [21]

Table 1 demonstrates that the number of SME units was 559841 in 2018. It shows 3,1\% decline compared to previous year results (567 131 business units). The total number of SMEs was 557122 in 2016, 531063 in 2015, and 265241 in 2014 [21]. Examining the sectoral division, the share of SMEs operating in service sector is the highest $(46,1 \% ; 258$ 298 SMEs). Nearly one-fifth of the SMEs (19,0\%; 106643 SMEs) are operating in trade. Further 17,0 $\%$ (95 315 SMEs) conduct their business activity in construction, $13,7 \%$ (76 454 SMEs) represent industry, and 4,1\% (23 131SMEs) provide agricultural activity. The long-term development of the sectoral structure of SMEs is characterized by a growing representation of the service sector, accompanied by a visible decline in trade [21]. Large proportion of entrepreneurs in our sample is selfemployed or run a limited liability company in terms of legal forms. According to the number of employees, $79,4 \%$ of the companies have less than 10 employees; $16,9 \%$ of them have less than 49 employees, and $3,7 \%$ of the companies reported less than 249 employees. The sample shows high representation of micro businesses. $99,39 \%$ of the enterprises in the sample fall under the category of small and medium-sized enterprise based on the number of their employees. 


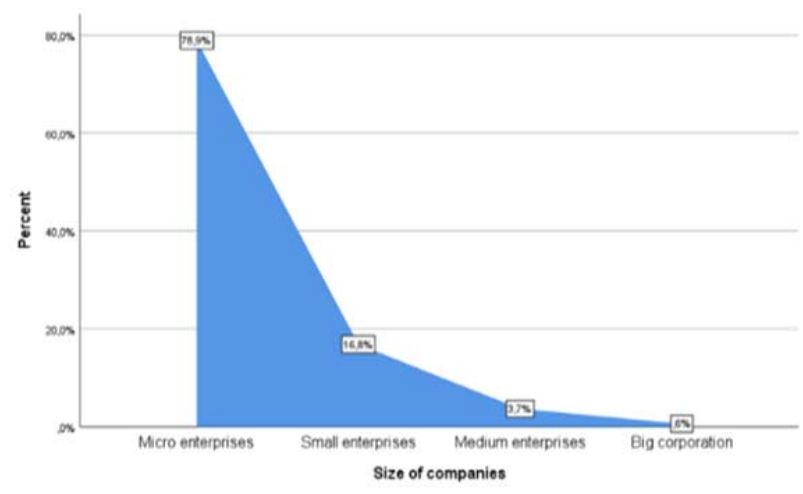

Figure 1. Distribution of businesses based on their size Source: own editing

As it was described, a large proportion of enterprises involved in our sample are sole proprietors. Less than a quarter of the respondents established a partnership with a friend or acquaintance. Only 3 respondents in our survey run a family business. $85 \%$ of the respondents established their business on their own, $8 \%$ bought and $6 \%$ inherited the business. Only $1 \%$ of the respondents are still involved with family business with their parents.

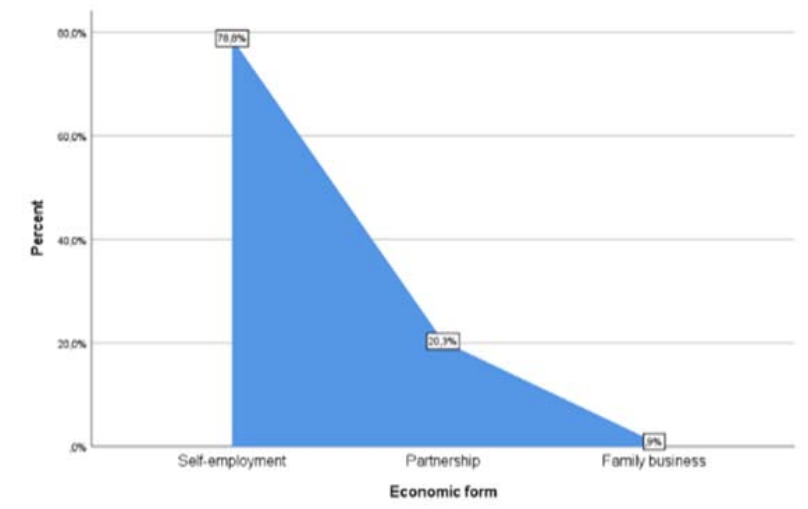

Figure 2. Distribution of enterprises according to type of economic form

Source: own editing

A common problem after establishing a business is that many businesses 3 years after their establishment cannot maintain their activity, and the owner is forced to close the business and quit the business activity. As we can see on Diagram 3, most of the enterprises involved in our survey have been conducting their business activity for more than 3 years. 40 enterprises from the total of 325 involved in our research sample ( 2 respondents did not provide answer) were founded between 2017 and 2019. Close to $50 \%$ is the ratio of those enterprises, which have been on the market for 4-14 years compared to 2019 data.

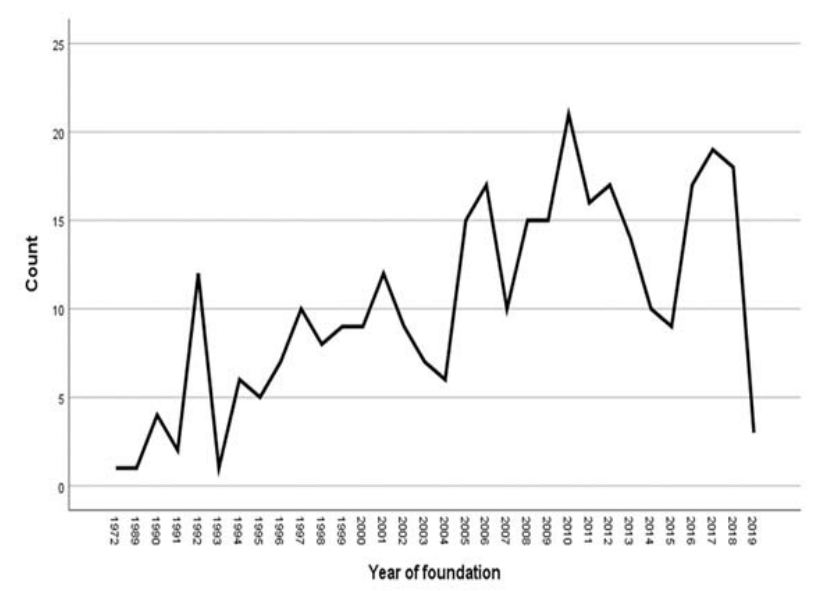

Figure 3. Distribution of enterprises based on the year of foundation

Source: own editing

Our research examined the financial sources the respondents used when starting their business. The results are presented in Diagram 2. We can see that the respondents used not only one type of financial source, but multiple sources of finance to start their business. The respondents used mainly their own savings at the beginnings, but many of the entrepreneurs starting their business applied also for a bank loan. The relatively low ratio of bank loans (less than 50\%) compared to using own capital for starting a business is a positive tendency. It is important for business to achieve a low level of indebtedness ratio and maintain financial reserves.

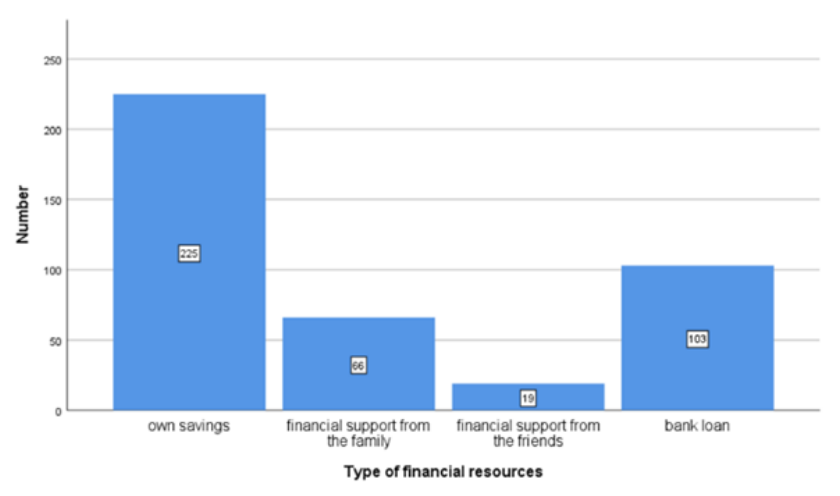

Figure 4. Distribution of start-up subsidies Source: own editing

Our research was focusing on the consensus of the respondents regarding the push and pull factors connected to starting a business. A 7-point scale was applied to measure the opinion of the respondents, where $1=$ "absolutely disagree" and $7=$ "completely agree". The respondents had to evaluate the listed motifs along these attributes. The summary table below illustrates the average values of the respondents connected to starting their business activity, and along the standard deviation the degree of consistency of the responses. We can see that the respondents in the sample are dominated by pull motivational factors when starting a business. The 9 pull motivation factors examined have a value above the mean. 
Table 2. The motives of enterprises in relation to start business

\begin{tabular}{|c|c|c|c|}
\hline & $\mathbf{N}$ & Mean & $\begin{array}{c}\text { Std. } \\
\text { Deviation }\end{array}$ \\
\hline $\begin{array}{l}\text { I started my own business, } \\
\text {...would like to make more } \\
\text { money - pull }\end{array}$ & 327 & 5,85 & 1,522 \\
\hline $\begin{array}{l}\text { I started my own business, } \\
\text {...would like to be my own } \\
\text { boss. - pull }\end{array}$ & 326 & 5,82 & 1,343 \\
\hline $\begin{array}{l}\text { I started my own business, } \\
\text {...would like to ensure well- } \\
\text { being for myself. - pull }\end{array}$ & 326 & 5,80 & 1,486 \\
\hline $\begin{array}{l}\text { I started my own business, } \\
\text {...would like to realize } \\
\text { myself. - pull }\end{array}$ & 327 & 5,77 & 1,407 \\
\hline $\begin{array}{l}\text { I started my own business, } \\
\text {...would like to achieve } \\
\text { financial independence. - } \\
\text { pull }\end{array}$ & 325 & 5,69 & 1,466 \\
\hline $\begin{array}{l}\text { I started my own business, } \\
\text {...would like to achieve } \\
\text { independence in non- } \\
\text { financial terms (time) - pull }\end{array}$ & 324 & 5,33 & 1,727 \\
\hline $\begin{array}{l}\text { I started my own business, } \\
\text {...have a desire for self- } \\
\text { development. - pull }\end{array}$ & 323 & 5,30 & 1,618 \\
\hline $\begin{array}{l}\text { I started my own business, } \\
\text {...would like to be } \\
\text { recognized by others. - pull }\end{array}$ & 323 & 4,44 & 1,953 \\
\hline $\begin{array}{l}\text { I started my own business, } \\
\text {...recognized demand for } \\
\text { new products and services. } \\
\text { - pull }\end{array}$ & 325 & 4,35 & 1,929 \\
\hline $\begin{array}{l}\text { I started my own business } \\
\text {...was dissatisfied with my } \\
\text { previous job. - push }\end{array}$ & 326 & 3,88 & 2,110 \\
\hline $\begin{array}{l}\text { I started my own business, } \\
\text {...had no other choice. - push }\end{array}$ & 326 & 2,68 & 2,984 \\
\hline $\begin{array}{l}\text { I started my own business, } \\
\text {...my position at my } \\
\text { previous workplace became } \\
\text { insecure. - push }\end{array}$ & 325 & 2,49 & 1,786 \\
\hline $\begin{array}{l}\text { I started my own business } \\
\text {...felt hopeless about my } \\
\text { situation. - push }\end{array}$ & 325 & 2,32 & 1,704 \\
\hline $\begin{array}{l}\text { I started my own business, } \\
\text {...had disagreements with my } \\
\text { manager at my workplace. - } \\
\text { push }\end{array}$ & 325 & 2,24 & 1,719 \\
\hline $\begin{array}{l}\text { I started my own business, } \\
\text {...had workplace conflicts. - } \\
\text { push }\end{array}$ & 324 & 2,20 & 1,629 \\
\hline $\begin{array}{l}\text { I started my own business, } \\
\text {...was unemployed earlier. - } \\
\text { push }\end{array}$ & 320 & 2,04 & 1,761 \\
\hline $\begin{array}{l}\text { I started my own business, } \\
\text {...inherited the business from } \\
\text { family member. - push }\end{array}$ & 324 & 1,96 & 1,747 \\
\hline Valid N (listwise) & 302 & & \\
\hline
\end{tabular}

Source: own editing
The motives with the highest average values are the demand for more money, independence and ensuring well-being. These were the most motivating factors for the respondents. The greatest agreement was achieved in case of "being my own boss" since the value of standard deviation is the smallest along this variable. With regard to push factors, we would like to highlight that dissatisfaction with previous workplace has most influenced the respondents to start their own business. It can be observed that the greatest degree of disagreement in the answers of our respondents regarding the variance developed in connection to become recognized by others. In the case of this variable, the respondents provided similar evaluation for agreement, disagreement and indifference regarding the statement. The success of entrepreneurs was measured through the individual's attitude towards the business success. Based on the collected data we can summarize that most of our respondents believe that they run a successful business.

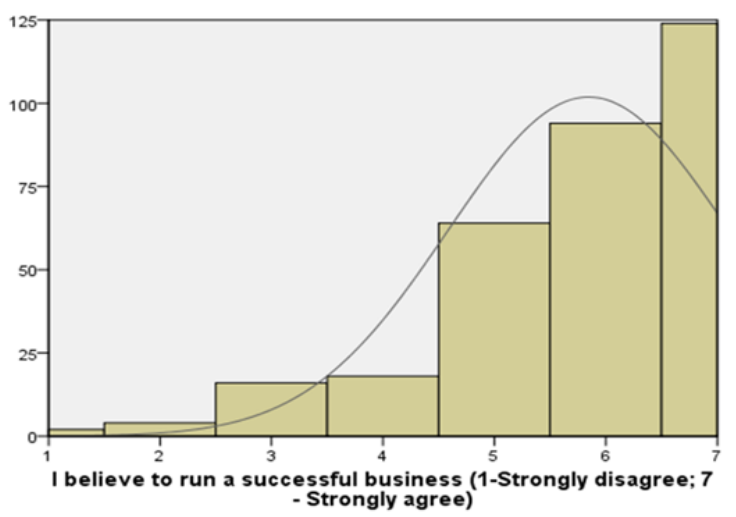

Figure 5. „I believe to run a successful business”distribution of answers according to respondents Source: own editing

The further part of the study examined the relationship between the motivational factors and the feeling of running a successful business. We were interested in whether the pull or push factors are the one playing a relevant role in relation to the attitude of running a successful business. Each of the variables measured are metric variables, so we decided to conduct a correlation calculation. Correlation calculation is used to measure the strength and direction of a linear relationship between the variables. It is shown by the Pearson's correlation coefficient, where the value can move in the interval of -1 to 1 . The bivariate correlation analysis is summarized in Table 3 . The table shows that in the case of 10 of the 19 motivational factors we could detect a correlation towards successful business leadership. Within six of these ten variables, the relationship is acceptable at a significance level of $1 \%$ and at $5 \%$ with the remaining 4 variables

In the case of pull factors, with the exception of the variable "I found a demand for new product/service", the results show a medium or weak one-way relationship with the attitude of successful business management. According to the facts mentioned above, our Hypothesis H01 "There is no relationship 
between the pull factors responsible for starting business and the entrepreneur's attitude feeling successful" can be rejected, and the H11 "There is a relationship between the pull factors and the entrepreneur's attitude feeling successful" can be accepted.

Table 3. Summary of the correlation analysis

\begin{tabular}{|c|c|c|c|}
\hline $\begin{array}{c}\text { Push/ } \\
\text { Pull }\end{array}$ & $\begin{array}{l}\text { I started my own } \\
\text { business... }\end{array}$ & $\begin{array}{l}\text { Pearson } \\
\text { Correla- } \\
\text { tion coe- } \\
\text { fficient }\end{array}$ & $\begin{array}{l}\text { Sig. (2- } \\
\text { tailed) }\end{array}$ \\
\hline Pull & $\begin{array}{l}\text {... would like to } \\
\text { make more money. }\end{array}$ & $.174^{* *}$ & ,002 \\
\hline Pull & $\begin{array}{l}\text {... would like to be } \\
\text { my own boss. }\end{array}$ & $.262^{* *}$ &, 000 \\
\hline Pull & $\begin{array}{l}\text {...would like to } \\
\text { provide well-being } \\
\text { for myself. }\end{array}$ & $.199^{* *}$ &, 000 \\
\hline Pull & $\begin{array}{l}\text {... would like to } \\
\text { realize myself. }\end{array}$ & $.305^{* *}$ &, 000 \\
\hline Pull & $\begin{array}{l}\text {...would like to } \\
\text { achieve financial } \\
\text { independence. }\end{array}$ & $.293^{* *}$ & ,000 \\
\hline Pull & $\begin{array}{l}\text {...would like to } \\
\text { achieve } \\
\text { independence in } \\
\text { non-financial terms. } \\
\text { (e.g. time) }\end{array}$ & $.133^{*}$ & ,017 \\
\hline Pull & $\begin{array}{l}\text {...have a desire for } \\
\text { self-development. }\end{array}$ & $.201^{* *}$ &, 000 \\
\hline Pull & $\begin{array}{l}\text {... would like to be } \\
\text { recognized by } \\
\text { others. }\end{array}$ & $.128^{*}$ &, 022 \\
\hline Pull & $\begin{array}{l}\text {...detected demand } \\
\text { for new product or } \\
\text { service. }\end{array}$ & & \\
\hline Push & $\begin{array}{l}\text {...was dissatisfied } \\
\text { with my previous } \\
\text { job. }\end{array}$ & & \\
\hline Push & $\begin{array}{l}\text {...had no other } \\
\text { choice. }\end{array}$ & & \\
\hline Push & $\begin{array}{l}\text {...my position at } \\
\text { my previous } \\
\text { workplace became } \\
\text { insecure. }\end{array}$ & $-.122^{*}$ & 029 \\
\hline Push & $\begin{array}{l}\text {...felt hopeless } \\
\text { about my situation. }\end{array}$ & $-.144^{*}$ &, 010 \\
\hline Push & $\begin{array}{l}\text {...had disagreement } \\
\text { with my boss at } \\
\text { previous workplace. }\end{array}$ & & \\
\hline Push & $\begin{array}{l}\text {...had conflicts at } \\
\text { my previous } \\
\text { workplace. }\end{array}$ & & \\
\hline Push & $\begin{array}{l}\text {...was unemployed } \\
\text { earlier. }\end{array}$ & & \\
\hline Push & $\begin{array}{l}\text {...inherited the } \\
\text { business from my } \\
\text { family member. }\end{array}$ & & \\
\hline
\end{tabular}

**. Correlation is significant at the 0.01 level (2-tailed),

*. Correlation is significant at the 0.05 level (2-tailed). Source: own editing
Among the pull motivation factors "I want to realize myself" factor showed a positive moderate relationship with the attitude of feeling successful. This relationship is presented on the following figure. The figure shows that there is mostly positive relationship between the two variables, and the scattered responses confirm a medium-strength relationship between the variables.

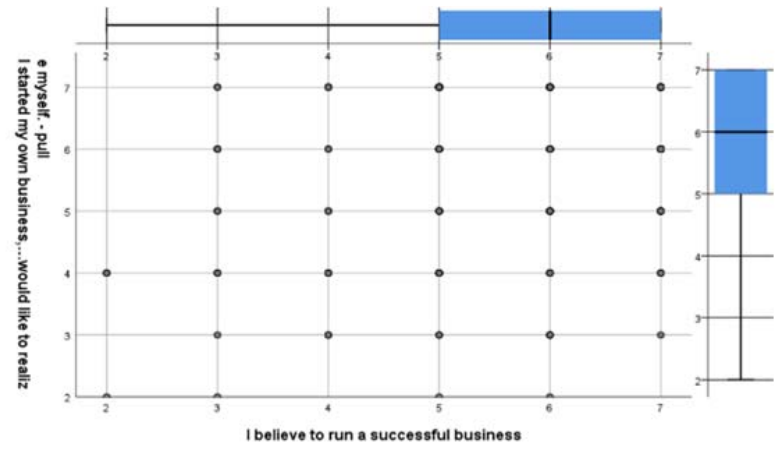

Figure 6. There is a positive relationship between the motivation factor "I want to realize myself" and the sense of success attitude

In the case of push factors, a weak, negative relationship can be detected in the case of two of the eight variables. The negative relationship between variables can be explained by the fact that the respondents mainly disagreed with the statements, so they do not feel they have become entrepreneurs because they experienced uncertainty at their previous workplace or felt their situation hopeless. Besides that, they were detected to feel a high level of satisfaction. Based on these results, we can accept our hypothesis $\mathrm{HO} 2$ "There is no relationship between the push factors responsible for starting business and the entrepreneur's attitude feeling successful.", since only two of the eight variables showed a negative relationship related to the attitude of successful business management.

\section{Conclusion}

Since the research is in early stage and we will continue our research activity, we would like to summarize that the issue of employee motivation is approached and discussed from different perspectives. The discussion of the issue seemed to be up-to-date in terms of push and pull factors. In most of the cases, people quit their employment because they are pushed to do as a result of certain push factors, and these have fundamental influence on decision or motivation to start their own business. Based on our partial results, we can summarize that the greatest motivation factor is the desire for independence, self-realization and utilization of own skills and abilities. The desire to have a job the individual feels positive about and provides a 
possibility for self-realization can be listed among pull factors, which has a positive impact on the success of business the entrepreneur encounters many obstacles. Motivation to do business is not only important from the perspective of the individual or in terms of strategic measures applied by government, but is also important for businesses, which can lose their employees because of dissatisfaction.

\section{Acknowledgements}

This research was supported by the project VEGA 1/0813/19 "Managing the development of innovative and start-up forms of businesses in international environment and verification of INMARK concept", which has received funding from the Ministry of Education, Science, Research and Sport of the Slovak Republic.

\section{References}

[1]. Androniceanu, A., Sabie, O. M., \& Pegulescu, A. (2020). An integrated approach of the human resources motivation and the quality of health services. Theoretical and Empirical Researches in Urban Management, 15(1), 42-53.

[2]. Baum, J. R., \& Locke, E. A. (2004). The relationship of entrepreneurial traits, skill, and motivation to subsequent venture growth. Journal of applied psychology, 89(4), 587.

DOI: 10.1037/0021-9010.89.4.587.

[3]. Baez, M. A. C., Stobäus, C. D., \& Mosquera, J. J. M. (2016). School Physical Education: Welfare, Motivation and Positive Psychology. Education, 7, 2476-2489. doi: 10.4236/ce.2016.716235.

[4]. Belas, J., Kmecova, I., \& Cepel, M. (2020). Availability of human capital and the development of the public infrastructure in the context of business activities of SMEs. Administratie si Management Public, (34), 27-44.

[5]. Bertan, S. (2020). Key Success Factors for Doing Business in Hot Air Balloon Riding. Journal of Tourism and Services, 11(20), 124-131.

DOI: 10.29036/jots.v11i20.131.

[6]. Butler, J. E., Doktor, R., \& Lins, F. A. (2010). Linking international entrepreneurship to uncertainty, opportunity discovery, and cognition. Journal of International Entrepreneurship, 8(2), 121-134. DOI: 10.1007/s10843-010-0054-x.

[7]. Ciobanu, A., Androniceanu, A., \& Lazaroiu, G. (2019). An Integrated Psycho-Sociological Perspective on Public Employees' Motivation and Performance. Frontiers in Psychology, 10, 36. DOI: $10.3389 /$ fpsyg.2019.00036

[8]. Farhangmehr, M., Gonçalves, P., \& Sarmento, M. (2016). Predicting Entrepreneurial Motivation among University Students: The Role of Entrepreneurship Education. Education \& Training, 58, 861-881.

[9]. Gray, C. (2002). Enterprise and culture. Routledge.

[10]. Jašková, D. (2019). Assessment of social development in Slovakia in the context of human resources. Central European Journal of Labour Law and Personnel Management, 2(2), 21-32.

DOI: $10.33382 /$ cejllpm.2019.03.02
[11]. Korauš, A., Havierniková, K., Gombár, M., Černák, F., \& Felcan, M. (2020). Dimensions and their elements affecting the innovative activities of agricultural SMEs toward their sustainable development. Entrepreneurship and Sustainability Issues, 8(2), 1142. DOI: 10.9770/jesi.2020.8.2(68)

[12]. Ludbrook, F., Michalikova, K.F., Musova, Z., Suler, P. (2020). Business models for sustainable innovation in industry 4.0: Smart manufacturing processes, digitalization of production systems, and data-driven decision making. Journal of SelfGovernance and Management Economics, 7(3), 2126.

[13]. McClelland, D. C. (1961). The Achieving Society Van Nostrand Reinhold. Princeton, NJ.

[14]. Naffziger, D. W., Hornsby, J. S., \& Kuratko, D. F. (1994). A proposed research model of entrepreneurial motivation. Entrepreneurship theory and practice, 18(3), 29-42.

[15]. Neck, H. M., \& Greene, P. G. (2011). Entrepreneurship education: known worlds and new frontiers. Journal of small business management, $49(1), 55-70$. DOI: 10.1111/j.1540-627X.2010.00314.x.

[16]. Nosková, M., \& Peráček, T. (2019). Termination of employment in the Slovak Republic as a key issue of HR Management. Central European Journal of Labour Law and Personnel Management, 2(2), 4459.

DOI: 10.33382/cejllpm.2019.03.04

[17]. Peráček, T., Vilčeková, L., \& Strážovská, L. (2020). Selected Problems of Family Business: A Case Study from Slovakia. Acta Polytechnica Hungarica, 17(7). DOI: 10.12700/APH.17.7.2020.7.8

[18]. Prokopenko, O., Osadchenko, I., Braslavska, O., Malyshevska, I., Pichkur, M., \& Tyshchenko, V. (2020). Competence approach in future specialist skills development. International Journal of Management, 11(4), 645-656.

DOI: 10.34218/IJM.11.4.2020.062

[19]. Prokopenko, O. V., \& Kornatowski, R. (2018). Features of modern strategic market-oriented activity of enterprises. Marketing and management of innovations, (1), 295-303.

DOI: $10.21272 / \mathrm{mmi} .2018 .1-22$

[20]. Santos, V., \& García, T. (2011). Business motivation and informational needs in internationalization. Journal of International Entrepreneurship, 9(3), 195. DOI: 10.1007/s10843-011-0077-y.

[21]. Slovak Business Agency (SBA). 2019. Správa o stave malého a stredného podnikania v Slovenskej republike v roku 2018 - ročná správa.

Retrieved from: http://www.sbagency.sk/sites/default/files/pictures/spr ava o stave msp_v sr_v roku 2016.pdf. [accessed: 12 November 2020].

[22]. Gerry, S., Dan, B., \& Jerry, S. (2005). The motivation to become an entrepreneur. International Journal of Entrepreneurial Behaviour \& Research, 11(1), 42-57. 
[23]. Skinner, B. F. (1987). Whatever Happened to Psychology as the Science of Behavior?. American Psychologist, 42(8), 780-786.

[24]. Ślusarczyk, B., Haque, A.U. (2019). Public services for business environment: Challenges for implementing industry 4.0 in polish and canadian logistic enterprises. Administratie si Management Public 2019(33), pp. 57-76

[25]. Smith, J. K., Smith, R. L., \& Bliss, R. T. (2011). Entrepreneurial Finance: Strategy, Valuation, and Deal Structure. Stanford University Press.

[26]. Snieska, V., Navickas, V., Grencikova, A., Safrankova, J. M., \& Sikyr, M. (2020). Fundamental Human Resource Management Practices Aimed at Dealing With New Challenges in the Labour Market. Transformations in Business \& Economics, 19(2).

[27]. Schumpeter, J. A. (1987). Teória hospodárského vývoja: analýza podnikatel'ského zisku, kapitálu, úveru, úroku a kapitalistického cyklu. Pravda.
[28]. Súbertová, E. kolektív. (2011). Podnikanie v malých a stredných podnikoch. Kartprint, $120 \mathrm{p}$.

[29]. Tamulevičienè, D., Androniceanu, A., \& Androniceanu, A. (2020). Selection of the indicators to measure an enterprise's value and its changes in the controlling system for medium-sized enterprises. Entrepreneurship and Sustainability Issues, 7(3), 1440-1458.

[30]. Taylor, M. P. (1996). Earnings, independence or unemployment: why become self-employed?. Oxford Bulletin of Economics and Statistics, 58(2), 253-266. DOI: 10.1111/j.1468-0084.1996.mp58002003.x.

[31]. Vigliarolo, F. (2020). Economic phenomenology: fundamentals, principles and definition. Insights into Regional Development, 2(1), 418-429. DOI: 10.9770/IRD.2020.2.1(2)

[32]. Zahra, S. A., Korri, J. S., \& Yu, J. (2005). Cognition and international entrepreneurship: implications for research on international opportunity recognition and exploitation. International business review, 14(2), 129-146. DOI: 10.1016/j.ibusrev.2004.04.005. 